\section{JIBM}

Journal of International Business and Management (JIBM) Journal Homepage: https://rpajournals.com/jibm

\title{
A Social study on the Human Rights of the Trans-community of a Developing Country, Pakistan
}

\author{
Liaquat Ali Khan' \\ Nusrat Hafiz ${ }^{2}$ \\ Marjea Jannat Mohua ${ }^{3}$ \\ BRAC Business School, BRAC University, Bangladesh ${ }^{12}$ \\ Putra Business School (PBS), University Putra Malaysia (UPM), Malaysia ${ }^{23}$
}

\begin{abstract}
Preventing human rights violations and social exclusion of all humans, including transgender- is key to sustainable and equitable development. As one of the most marginalized communities of any society, the trans-community faces differential treatment, especially from developing countries. The trans-community is often a victim of social exclusion discriminations in public and private spheres. The present study explores their social exclusion experience and its impact in the light of Sustainable Development Goals (SDGs) of the UN Charter. A sample size of 150 was taken out using the snowball sampling method in the Sargodha City of Pakistan. It was found that the trans community is considered a marginalized segment of society, and their families neither own them nor give them their due share in inheritance. Also, to become part of the guru system inherently rooted in enslavement, they have to adhere to a range of stringent rules. Hence, social exclusion has violated various SDGs, including goals 3, 10 , and 16. The findings strongly suggest that interventions to increase social inclusion, reduce gender-based discrimination, violence, and physical abuse, and facilitate access to quality medical care should be considered part of a comprehensive approach for preventing risky behavior in trans-populations. The researchers suggest a set of actionable recommendations for the well-being of the trans-communities of the studied location. The recommendations can be implemented for marginalized communities in other countries of similar development status.
\end{abstract}

Keywords: Social study, harassment, human rights, discrimination, trans-community, Pakistan

*Corresponding author: Nusrat Hafiz

Email: nusrat.hafiz@bracu.ac.bd; nusrat.phd mgt18@grad.putrabs.edu.my

DOI: https://doi.org/10.37227/JIBM-2022-02-5309

\section{Introduction}

The holistic realization of human potential has aimed to be preserved by the Sustainable Development Goals (SDGs) in terms of human rights, dignity, non-discrimination, and equality across all races, color, sex, language, religion, political orientation, national or social origin, property, birth, and disability. Despite the overarching efforts by United Nations, the human rights progress for a transgender person has remained inadequate, especially from developing countries. The culture of developing countries is made up of established practices and systems that assume specific identities as default. Transgender individual or Third Gender is part of a subculture that does not 
conform to the identity's usual social expectations regarding appearance, signals, movements, and other traits; a transgender person has a unique and special gender expression. Unfortunately, the trans community continues to live in highly hostile contexts.

In backward societies, transgender people lead a life of humiliation due to the encounter's social defiance, humiliation, and phraseology. They experience different types of discrimination based on their identities and presentations. Transphobia is discrimination based on our status as transgender or gender-nonconforming people. Transphobia overlaps with homophobia (discrimination against gay, lesbian, and bisexual people), sexism (discrimination based on our perceived sex), and misogyny (hatred or dislike of women). As an obvious outcome of transphobia, gay men often are considered more feminine, and gender-nonconforming individuals are bullied even at a young age.

The regulations, policies, and practices to protect the rights of trans-community suffer complex procedures, limit access to justice, and cause severe violations of their human rights. If the situation is not addressed and attended timely, the social exclusion of the trans-community will inflate the already damaged physical and mental health, inadequate access to education and employment, and loss of opportunities for economic and social advancements (Divan et al., 2016). Therefore, exploring the social discrimination and its impact on the lives of trans-community in developing countries is a timely need. The research objectives of the present study are:

(i) To explore the social exclusion experience of the transgender community of Pakistan.

(ii) To analyze the impact of such social exclusion in the light of human rights as mentioned in the SDGs.

The present study is conducted on Sargodha City of Sindh, Pakistan. It is expected that the study's findings will help those agencies, organizations, psychologists, and social workers who work relentlessly towards the upliftment of the minority community from marginalization.

\section{Present Status}

\section{Literature Review}

The United Nations Development Programme (UNDP) views the marginalized communities, including the trans community, through the lens of human rights and advances a range of development solutions such as poverty reduction, improved governance, active citizenship, and access to justice. The transgender in Pakistani society is commonly known as Hijra or Khusra. Under the umbrella term of Hijra, several sub-communities such as eunuchs, transvestites, bisexuals, hermaphrodism, etc. Unfortunately, many are still considered the weakened, emasculated, womanly, explicitly peculiar, or even useless gender (Mal, 2018). They often isolate themselves in selfsufficient and well-stitched groups, where a pioneer or teacher known as the guru adopts young transsexuals whom their parents disown due to social stigma and personal shame associated with them (Wijngaarden et al., 2013).

After the Senate, the National Assembly has passed a bill to recognize the third gender, the transgender people in the country, and provide them with fundamental human rights. The country's first transgender Ayesha Mughal was part of the National Task Force in preparation for the Defense Gender Person of Rights Bill 2018, which has now become part of the country's law. The Pakistani parliament and the Senate have legislated for the rights of transgender people. Transgender people are participating in elections in Pakistan more than in the past, proving their rights. The Pakistani state has begun enacting laws on the rights of eunuchs to show their bright face in the world. Pakistani passports have been issued, and voting rights have been given. They have also been counted in the census. The laws are indeed changing, but social behavior for the eunuchs did not improve significantly.

Trans people experience enormous hate incidents, and transphobic harassment from their community hardly receives any financial help. The current situation of Covid-19 has a seriously significant impact on transgender people as all their other resources or earning activities are paused. Due to a lack of earning sources, their savings depleted, and they are seeking assistance from the 
people and local community the people and local community. Also, due to the absence of proper health care and supporting behavior by health staff, transgender people are the most vulnerable to covid-19 (Mirabella et al., 2021).

\section{Social Discrimination on Transgender People}

Extant literature supports the fact that there is sufficient discrimination against transgender people in Pakistan, as Ahmed et al. (2021) studied the comparative impact of discrimination in society and got the victim of injustice and harassment. It has also been found that their low social position makes them vulnerable to physical, emotional, and voluptuous assault. Some transgender people face various diseases, which compels them to face assaults from the community. They face violence and hurdles even in their attempt to break the stereotype. Falak et al. (2020) found a significant positive relationship between perceived discrimination, social support, and psychological distress in transgender individuals; and a significant negative relationship between perceived discrimination and social support.

In Pakistan, trans individuals face difficulty in schools, shelters, hospitals, potential employers, or even police stations or medical centers in revealing their gender expressions that do not "match" the gender designations they provided on the record of birth certificates, health cards, passports, drivers' licenses, school, and medical documents. Trans young people want to continue their education, but school administration, teachers, and family members do not always support and encouragement. Trans-individuals also experience partial treatment when entering a shelter, as they were not comfortable sharing homes with either men or women. They are also deprived of medical treatment due to doctors' denial (Balsam, Beadnell \& Molona, 2013; Basow \& Thompson, 2012), and the majority of trans-individuals choose to take alternative medicine for treating ailments (Khan et al., 2009) as they are unable to decide whether to keep them in the men's ward or to women (Mughal et al., 2019).

Overall, unemployment and underemployment rates are high among the transgender population in the sub-continent. The trans-community is subject to unfair treatments like verbal abuse, physical and voluptuous violence; false arrests; Such as denial of share in their ancestral property, services, and admission to educational institutions; and victimization in multiple settings like family, educational institutions, workplace, health care settings, public spaces. Leaving a job may result in the loss of future earnings and upward mobility due to their particular gender identity (Yasin \& Jauhar, 2018).Mohydin (2018) admitted that the family members of trans-community also rarely admit that their loved ones can be transgender. There is an internalized shame in coming forward as transgender and committing to the dangers of that association.

Concerning molestation cases of trans-community, while Sterzing et al. (2019) found that several trans-adults are victimized, (Atteberry-Ash et al. 2020) revealed that a maximum number of forced rapes are done on trans-highschoolers. According to Shah et al. (2018), the transgender community is socially excluded by the Pakistani society, where they experience high levels of physical abuse and face discriminatory behavior in daily life. Evidence shows that such attitudes make them vulnerable to risky behaviors, forcing them to become commercial prostitutes, beggars, drugs users, and even suicide attempters. Rehan et al. (2009) found that the guru is responsible for managing his house's funds and meeting their needs. Hence, they are expected to turn their earnings over to the guru even at the cost of commercial prostitution.

Unfortunately, such abusive violence can have a lifelong effect on trans-community. The Transgender Advocacy Organizations indicate that these individuals do not seek supportive services (Burnes, Dexter, Richmond, Singh, \& Cherrington, 2016) for fear of being "outed" in their community; and secondly, due to a prior negative experience with medical and social service providers.

\section{Methodology}

Considering the nature of the study, the researcher adopted the qualitative method of the research. The second-largest province of Pakistan, named Punjab, is considered the study area. There are nine 
divisions of Punjab, Pakistan, divided into 36 districts and subdivided into tehsils (Government of Pakistan, 2013). The transgender people residing in Sargodha city were the target population of this research undertaking. The researcher was interested in delving deep into the differential treatment meted out to the transgender community in Sargodha city and uncovering the harassment they face in the public and private sphere. Primary data was collected from transgender people residing in Sargodha city through a closed and open-ended questionnaire to unearth the social issues and discrimination. The Snowball inspecting approach was used, a popular method and used in recent studies such as Kade (2021). In this study, we are using a sample size of 150. According to Compton (2018), research on hidden populations, for example, trans community (Zamantakis, 2020), leads to practical insights even if small samples are used. Echoing with Compton (2018), the sample size seems acceptable.

Table 1: Demographic Profile

\begin{tabular}{|c|c|c|}
\hline Age grouping & Frequency & Percentage \\
\hline $15-25$ & 47 & 31.3 \\
\hline 26-35 & 64 & 42.7 \\
\hline $36-45$ & 30 & 20 \\
\hline $46-55$ & 9 & 6 \\
\hline Total & 150 & 100 \\
\hline Educational Qualification & Frequency & Percentage \\
\hline Illiterate & 32 & 21.3 \\
\hline Primary & 49 & 32.7 \\
\hline Middle & 22 & 14.7 \\
\hline Matriculation & 24 & 16 \\
\hline Intermediate & 13 & 8.7 \\
\hline Graduation & 5 & 3.3 \\
\hline Only can recite & 5 & 3.3 \\
\hline Total & 150 & 100 \\
\hline Occupation Status & Frequency & Percentage \\
\hline Dancing & 59 & 39.3 \\
\hline Singing & 14 & 9.3 \\
\hline Self-employment & 15 & 10 \\
\hline Beggary & 26 & 17.3 \\
\hline Dancing \& prostitution & 16 & 10.7 \\
\hline Beggary \& prostitution & 6 & 4 \\
\hline Dancing \& self-employment & 5 & 3.3 \\
\hline $\begin{array}{lll}\text { Dancing, } & \text { singing } & \& \\
\text { courtesanship }\end{array}$ & 5 & 3.3 \\
\hline Dancing \& beggary & 4 & 2.7 \\
\hline Total & 150 & 100 \\
\hline Personal income & Frequency & Percentage \\
\hline
\end{tabular}




\begin{tabular}{|c|c|c|}
\hline $1000-10000$ & 41 & 27.3 \\
\hline $10001-20000$ & 57 & 38 \\
\hline 20001-30000 & 30 & 20 \\
\hline $30001-40000$ & 10 & 6.7 \\
\hline $40001-50000$ & 3 & 2 \\
\hline $50001-60000$ & 6 & 4 \\
\hline $60001-70000$ & 3 & 2 \\
\hline Total & 150 & 100 \\
\hline Marital status & Frequency & Percentage \\
\hline Married & 12 & 8 \\
\hline Single & 76 & 50.7 \\
\hline In a relationship & 32 & 21.3 \\
\hline Cohabiting with someone & 30 & 20 \\
\hline Total & 150 & 100 \\
\hline Number of siblings & Frequency & Percentage \\
\hline Brothers & 20 & 13.3 \\
\hline Sisters & 30 & 20 \\
\hline Transgender & 3 & 2 \\
\hline Brothers \& sisters & 92 & 61.3 \\
\hline Brothers \& transgender & 2 & 1.3 \\
\hline Sisters \& transgender & 3 & 2 \\
\hline Total & 150 & 100 \\
\hline Nature of relationship & Frequency & Percentage \\
\hline Good & 60 & 37.5 \\
\hline Bad & 100 & 62.5 \\
\hline Total & 150 & 100 \\
\hline $\begin{array}{l}\text { Who takes away the } \\
\text { respondent's income }\end{array}$ & Frequency & Percentage \\
\hline Guru & 13 & 8.7 \\
\hline Family & 55 & 36.7 \\
\hline Himself & 52 & 34.7 \\
\hline All of above & 30 & 20 \\
\hline Total & 150 & 100 \\
\hline Financial support & Frequency & Percentage \\
\hline Brother/sister & 10 & 6.7 \\
\hline Friends & 49 & 32.7 \\
\hline
\end{tabular}




\begin{tabular}{|c|c|c|}
\hline Philanthropist & 4 & 2.7 \\
\hline Father/mother & 18 & 12 \\
\hline Guru & 23 & 15.3 \\
\hline No one & 33 & 22 \\
\hline Friend \& guru & 13 & 8.7 \\
\hline Total & 150 & 100 \\
\hline Presently living & Frequency & Percentage \\
\hline Alone & 18 & 12 \\
\hline With family & 25 & 16.7 \\
\hline Cohabiting with someone & 24 & 16 \\
\hline Living with your community & 78 & 52 \\
\hline Guru \& friend & 5 & 3.3 \\
\hline Total & 150 & 100 \\
\hline Condition of living house & Frequency & Percentage \\
\hline Good & 89 & 59.3 \\
\hline Moderate & 25 & 16.7 \\
\hline Bad & 36 & 24 \\
\hline Total & 150 & 100 \\
\hline Societal labeling & Frequency & Percentage \\
\hline Hijra \& Khwajasara & 12 & 8 \\
\hline Khusra & 64 & 42.7 \\
\hline Murat & 9 & 6 \\
\hline Khusra \& Murat & 12 & 8 \\
\hline Hijra \& Khusra & 18 & 12 \\
\hline Haijra, Khusra \& Shemale & 10 & 6.7 \\
\hline Hijra, Khusra \& Murat & 13 & 8.7 \\
\hline Madam & 5 & 3.3 \\
\hline Khusra, Murat \& Shemale & 7 & 4.7 \\
\hline Total & 150 & 100 \\
\hline
\end{tabular}

In terms of age, the average age of the respondents was thirty years. The majority of the respondents, 42.7 percent, were in the age group 26-35 while the age group 15-25 years was at second number with 31.3 percent and 36-45 years were at the third number as it contains 20 percent. Regarding the educational qualification of the respondents, the majority of the respondents had a primary educational level, i.e., 32.7 percent, while 21.3 percent of the respondents were illiterate, and 14.7 percent of respondents had middle-level education, whereas only 3.3 percent had graduation level. One-fourth of respondents were of primary education level, which was a considerable percentage.

The research findings indicated that most respondents ( 39.3 percent) occupation was dancing while 17.3 percent were beggars, 10.0 percent were self-employed, and 10.7 percent were dancers and prostitutes. Thirty-eight percent (57) of the respondents had 100001-20000 Rupees as monthly income, and 27.3 percent had 1000-10000 Rupees as monthly income. Some 20 percent respondents 
had income level "between" 20001 to 30,000 while 6.7 percent had income level "between" 30001 to 40,000 whereas few respondents i.e., 2 percent had monthly income level "between" 4000150,000 . Only 2 percent of the respondents had 60001-70000 Rupees as monthly income. As far as respondents' marital status was concerned, the majority, 50.7 percent of the respondents, were single, 21.3 percent of respondents were in a relationship with someone, 20 percent of the respondents were cohabiting with someone, and only 8 percent of the respondents were married. The concept of cohabiting is identified as living with someone without marriage and fulfills their voluptuous needs and other basic needs. Regarding the number of the siblings of respondents, the majority of the respondents, 61.3 percent had brothers and sisters, 20 percent had sisters, 13.3 percent of the respondents had brothers, and 2 percent had transgender, whereas 2.0 percent had sisters \& transgender and 1.3 percent had brothers \& transgender.

According to the information provided by respondents about the nature of the relationship with their family members, more than half of respondents, 63.3 percent (95), had a good relationship with their family members. In comparison, 36.7 percent (55) of the respondent's relationship with their families was terrible. The study findings show that the majority of the respondents, 36.7 percent gave their monthly income to their families while 34.7 percent took their monthly income themselves. Some of the respondents, 8.7 percent, gave their monthly income to their guru. The respondents shared that when they had no source of income, the majority of the respondents, 32.7 percent, were supported by their friends. While 22 percent had no support, their gurus supported some 15.3 percent, and a few of them, 12.0 percent, were supported by their father \& mother while 6.7 percent of respondents supported by their brother \& sister in case of no income. Some 52 percent of respondents lived with their community members, while 16.7 percent lived with their families, some of them 16 percent cohabited with someone, and a few of them 12 percent lived alone.

More than half of the respondent's 59.3 percent living condition was good, 24 percent of respondents living condition was not so good, and the rest of the 16.7 percent living condition was moderate. The majority of the respondents ( 42.7 percent) were labeled by society as Khusra. Some 12 percent of respondents were labeled by society as Hijra \& Khusra. Some of the respondents, 3.3 percent, were labeled as madam by society. The majority of the respondents were labeled by society as Khusra. The word Khusra means Eunuch in Punjabi, Hindi \& Urdu. It was used throughout South Asia, and generally, it was used in the derogatory sense.

\section{Analysis and Discussion}

As most of the respondents were semi-literate, it was difficult to understand all questions. We translated the interview to the respondents in their local languages to make it easy to understand. Punjabi and Urdu elaborated on the research questions. We tried at my level best to follow ethical guidelines to conduct this research, either about the balanced power relationship between the researcher and interviewee or not to use direct questions about sensitive issues. The collected data was used to compute frequency and percentages. The findings were revealed and analyzed in the discussion section based on the computation.

Percentage distribution of the respondents according to their family behavior towards being identified as transgender.

Table 2: Family behavior

\begin{tabular}{|l|l|l|}
\hline Family behavior & Frequency & Percentage \\
\hline They accept you & 16 & 10.7 \\
\hline Treat inhumanly & 45 & 30.0 \\
\hline Punish you & 38 & 25.3 \\
\hline $\begin{array}{l}\text { Conceal your identity } \\
\text { Punish you, conceal your identity \& want to kill } \\
\text { you }\end{array}$ & 28 & 18.7 \\
\hline $\begin{array}{l}\text { Treat inhumanly \& punish you } \\
\text { Respect }\end{array}$ & 6 & 4.0 \\
\hline Total & 12 & 8.0 \\
\hline
\end{tabular}


Percentage distribution of the respondents according to their feelings on social labeling

\begin{tabular}{|l|l|l|}
\hline \multicolumn{1}{|c|}{ Table 3: Social Labelling } & \\
\hline Inferiority complex & Frequency & Percentage \\
\hline Uselessness & 7 & 4.7 \\
\hline Mentally upset & 11 & 7.3 \\
\hline Feeling of shame & 33 & 22.0 \\
\hline Guilt feeling & 41 & 27.3 \\
\hline Mentally upset \& guilt feeling & 5 & 3.3 \\
\hline Mentally upset \& feeling of shame & 8 & 5.3 \\
\hline Uselessness \& mentally upset & 10 & 6.7 \\
\hline $\begin{array}{l}\text { Uselessness, mentally upset, guilt feeling \& feeling } \\
\text { of shame }\end{array}$ & 6 & 4.0 \\
\hline Uselessness \& feeling of shame & 7 & 4.7 \\
\hline Uselessness, feeling of shame \& guilt feeling & 5 & 3.3 \\
\hline Uselessness \& want to kill them & 5 & 3.3 \\
\hline All of above & 5 & 3.3 \\
\hline Total & 7 & 4.7 \\
\hline
\end{tabular}

The distribution of the respondents according to their opinion about the psychological condition of being a social outcaste

\begin{tabular}{|l|l|l|}
\multicolumn{2}{c}{ Table 4: } & Psychological Condition \\
\hline Psychological condition & Frequency & Percentage \\
\hline Loneliness & 15 & 10.0 \\
\hline Guilt & 40 & 26.7 \\
\hline Fear of death & 9 & 6.0 \\
\hline Anger & 21 & 14.0 \\
\hline Self-pity & 10 & 6.7 \\
\hline Anxiety & 30 & 20.0 \\
\hline Loneliness \& guilt & 8 & 5.3 \\
\hline Loneliness, guilt \& fear of death & 5 & 3.3 \\
\hline Loneliness \& anxiety & 7 & 4.7 \\
\hline Loneliness, anger \& anxiety & 5 & 3.3 \\
\hline Total & 150 & 100 \\
\hline
\end{tabular}

Percentage distribution of the respondents according to their opinion about voluptuous harassment faced by transgender

Table 5: Voluptuous Harassment

\begin{tabular}{|l|l|l|}
\hline \multicolumn{1}{|c|}{ Voluptuous harassment } & Frequency & Percentage \\
\hline Unwelcome voluptuous advances & 18 & 12.0 \\
\hline $\begin{array}{l}\text { Requests for voluptuous favors } \\
\text { Verbal or physical harassment of a voluptuous } \\
\text { nature }\end{array}$ & 84 & 56.0 \\
\hline All of above & 24 & 16.0 \\
\hline $\begin{array}{l}\text { Unwelcome voluptuous advances \& requests } \\
\text { for voluptuous favors }\end{array}$ & 8 & 5.3 \\
\hline None of them & 9 & 6.0 \\
\hline Total & 7 & 4.7 \\
\hline
\end{tabular}


Percentage distribution of the respondents concerning consequentiality of non-submission to harassment

\begin{tabular}{|l|l|l|}
\hline \multicolumn{2}{|c|}{ Table 6: Non-submission } & \\
\hline Consequences of non-submission & Frequency & Percentage \\
\hline Retaliation & 10 & 6.7 \\
\hline Social isolation & 8 & 5.3 \\
\hline Bulling & 17 & 11.3 \\
\hline Objectification & 30 & 20.0 \\
\hline Life threats & 48 & 32.0 \\
\hline All of above & 8 & 5.3 \\
\hline Bullying \& life threats & 7 & 4.7 \\
\hline $\begin{array}{l}\text { Bullying \& retaliation } \\
\text { Bullying, objectification, Isolation, life threats \& } \\
\text { retaliation }\end{array}$ & 4 & 2.7 \\
\hline Bullying \& objectification & 10 & 6.7 \\
\hline Total & 8 & 5.3 \\
\hline
\end{tabular}

Percentage distribution of the respondents in their opinion about-faced harassment at the workplace Table 7: Workplace Harassment

\begin{tabular}{|l|l|l|}
\hline Harassment at workplace & Frequency & Percentage \\
\hline Hurtful attempts to undermine & 66 & 44.0 \\
\hline Embarrassing attempts to undermine & 12 & 8.0 \\
\hline Emotional distress & 24 & 16.0 \\
\hline Hurtful attempts to undermine \& emotional distress & 19 & 12.7 \\
\hline $\begin{array}{l}\text { Hurtful attempts to undermine, embracing attempts to } \\
\text { undermine \& emotional distress }\end{array}$ & 4 & 2.7 \\
\hline $\begin{array}{l}\text { Malevolent dealing, hurtful \& embracing attempts to } \\
\text { undermine \& odious dealing through pitiless attempts }\end{array}$ & 9 & 6.0 \\
\hline $\begin{array}{l}\text { Odious dealing through pitiless attempts to undermine } \\
\text { \& embarrassing attempts to undermine }\end{array}$ & 6 & 4.0 \\
\hline All of above & 10 & 6.7 \\
\hline Total & 150 & 100 \\
\hline
\end{tabular}

Percentage distribution of the respondents according to their opinion about services need to be rendered to the trans-community

Table 8: Community services

\begin{tabular}{|c|c|c|}
\hline Steps needed to ensure the social inclusion & Frequency & Percentage \\
\hline $\begin{array}{l}\text { Shelter homes for trans-community medical insurance \& } \\
\text { concession in traveling }\end{array}$ & 8 & 5.3 \\
\hline Medical insurance & 11 & 7.3 \\
\hline Vocational training & 13 & 8.7 \\
\hline Shelter homes for trans-community \& medical insurance & 10 & 6.7 \\
\hline Shelter homes for trans-community \& vocational training & 8 & 5.3 \\
\hline All of above & 100 & 66.7 \\
\hline Total & 150 & 100 \\
\hline
\end{tabular}

The respondents also shared about family's reactions to their transgender identity. The majority of the respondents, 30 percent, were treated inhumanly by their families because they are transgender. Moreover, more than one-fourth of the respondents, i.e., 25.3 percent, believed that their family members punished them. 18.7 percent of respondents' families forced them to conceal their identity. The respondents also shared their feelings on social labelling. The majority of the respondents, 27.3 
percent, felt ashamed when people labelled them, and 22 percent of the respondents were mentally upset. According to the information provided by respondents about their psychological condition on being a social outcast, the majority of the respondents, 26.7 percent, felt guilty being a member of a social outcast. Moreover, 20 percent of the respondents responded anxiety, 14 percent responded to anger, 10 percent loneliness, 6.7 percent self-pity, 6 percent feared death.

The findings show that regarding voluptuous harassment faced by transgender, the majority of the respondents, 56 percent received voluptuous requests by clients, and some 16 percent faced harassment nature of voluptuous favors, some of respondents' 12 percent were facing unwelcoming voluptuous advances, and only 4.7 percent did not face any harassment. Thirty-two percent of the respondents faced life threats when they rejected the requests of voluptuous nature, and 20 percent of the respondents faced objectification. Some of the respondents' 11.3 percent, faced bullying by the public. Most respondents faced life threats if they did not submit to harassment. This was a very problematic situation for the transgender community. Regarding harassment at the workplace, most of the respondents' 44 percent faced malicious attempts to undermine and, 16 percent faced emotional distress at public places.

The respondents expressed their opinion about those services which need to be rendered to the transgender community. It was found that more than half ( 66.7 percent) of the respondents wanted all services to need to be rendered to the transgender community. Whereas 8.7 percent of respondents shared that vocational training services need to be taken for rendering to the transgender. Whereas 7.3 percent of the respondents answered medical insurance, and 6.7 percent of the respondents wanted shelter homes for them \& medical insurance that needs to be rendered to the transgender community.

In a nutshell, the study's findings reveal that trans-individuals face differential treatment from society as they are considered a marginalized segment of society, and their families neither own them nor give them their due share in inheritance. They are not welcomed at the medical and schooling systems either. Also, to become part of the guru system inherently rooted in enslavement, they have to adhere to a range of stringent rules. The cost of such experience being paid by the trans-community is enormous, forcing them to live in extreme penury, homelessness, forced separation from parents, and absence of dignified jobs. Hence, this social exclusion experience adversely impacts them emotionally, psychologically, socially, and physically.

\section{Discussion}

The present study directly relates to advancing the rights of the trans-community by laying out various aspects of health, education, human rights of trans-community from a developing country's perspective. The findings of the present study are similar to those of Siddique et al. (2017) as both the study revealed that in Pakistan the transgender is ignored in every walk of life including, education, government jobs, health care, and life security that led them increased feelings of fear, anger, and more significant depression. Justin. E, Jana. J. Lee (2021) also echoed that such communities were treated with hostility and ignorance from all corners of Pakistan. Hafiz et al. (2022) revealed that since the economic productivity of a developing country can enhance if the number of individuals in the workforce grows relative to the number of dependents, the inclusion of the trans-community can contribute to the country's existing demographic dividends. During the COVID-19 pandemic, trans-participants shared their resilience stories, identifying how prior preparation fostered resilience; radical acceptance was a source of resilience (Aberu et al., 2021). Hence, it is high time that businesses need to mould the lives of trans workers to stay competitive in terms of their Diversity \& Inclusion (D\&I) efforts in the pandemic era.

Preventing human rights violations and social exclusion is key to sustainable and equitable development. This formula applies to trans people as well. Also, at least three of the targets out of 17 SDGs can be extended by serving the trans community. The underpinning support for trans people's health-related rights is contained in SDG 3 -"Ensure healthy lives and promote well-being for all at all ages". The human rights of trans-community are sustained on SDG 10 - "Reduce inequality within and among countries". Finally, to create resonance from trans-rights, we echo SDG 
16 - "Promote peaceful and inclusive societies for sustainable development. The above targets of UN's sustainable development goals provide access to justice for all and build effective, accountable, and inclusive institutions at all levels, including the trans-community of the country.

\section{Implications of the Study}

Employers and managers need to ensure that they respond to their legal responsibilities on trans issues and adhere to broader implementation of good practice on trans in the workplace. Maintaining a diverse pool of talents can become a unique competitive advantage for any organization. A more diverse workforce can be a potential source of strength for a company as through this tool, they can enhance their understanding of the diverse needs of diverse sets of customers. According to Hafiz et al. (2022), such achievement can effectively predict organizational sustainability.

Good practices must be adopted by the entire community. Trans-people should be allowed to have appropriate solutions for using the health care system, education, housing, public facilities, religious institutions, shopping malls, leisure, sports, etc. Every member of a society may add specific trans-services, such as the provision of toilets and changing facilities for trans people. Besides these initiatives, they can have systematic monitoring of the representation of trans people in the media. For instance, inaccurate media portrayal of trans people should be penalized. Also, anti-homophobic bullying strategies to be promoted at all levels of society to address bullying-related gender-variant behavior. The scenario provided in this study can help transgender activists achieve better health standards, access to justice, and social inclusion for transgender communities.

Though in Pakistan, things gradually and slowly have improved following the enactment of the Trans Protection Act 2018. However, Human rights abuses and prejudices based on gender identity are still rampant and a major challenge for Pakistan. Proper policies must be added to completely stop all sorts of stigmatization, discrimination, and violence that lead to forced trafficking, extortion, and forced prostitution. The government needs to adopt and implement pragmatic steps to alleviate the gravity of the situation, recognize their fundamental human rights, and adequately include them in society.

Indigenous peoples, including the trans-activists, can be the voice of the third gender and demand their rights (Alam, et al., 2019), as everyone should be treated equally regardless of their gender orientation. Their rights for community and citizenship should be adhered to, and transphobia must be handled. Developing and supporting a national online resource that demonstrates advice and information on a range of trans issues, including creating awareness against transphobic harassment, can help them feel engaged and included. Besides these, equality and equity must be established to achieve overall cultural change by accepting trans people in society.

\section{Recommendations}

Based on the above implications, we infer that trans social inclusion is essential to break the human rights obstructions. It will also ensure the holistic participation of the trans community in the human and social development process. The above-mentioned implications can be more sensible by:

i) acknowledging transgender identity as their legal personhood to demonstrate respect to their inherent dignity;

ii) ensuring zero harassment and discrimination against trans people at multiple levels;

iii) providing equal accessibility of resources and facilities in a non-stigmatizing, nondiscriminatory, and informed environment averting confidentiality breach or denial of services based on gender identity;

iv) establishing an inclusive education system for trans-students by providing equal curricular and extra-curricular activities opportunities.

\section{Research Limitations \& Directions for Future Research}

Undoubtedly, the findings derived from our study remain limited as the participants sampled from Sargodha city of Panjab state of Pakistan using cross-sectional data. Thus, we note that the participants might have been more empowered and diverse if approached from all over Pakistan or 
even using longitudinal data from the developing countries. Also, our small sample size could facilitate an in-depth consideration of the qualitative data gathered to interpret thematic patterns within the data and not simply label content domains (Braun and Clarke, 2013).

In addition, this social study mainly focused on the present discriminatory status and estrangement of the human rights of one of the most neglected minorities of the society, i.e., the transgender community. There was a greater volume of literature available in some areas such as employment (e.g., Hafiz et al., 2021; Hafiz et al., 2022) or social discrimination (e.g., Falak et al., 2020 Ahmed et al., 2021) but topics on the rights of trans people on other areas such as housing; education; media, leisure, and sports have been relatively scarce. The future study can focus on this scope. To preserve their human rights and address their holistic social issues, the frameworks elaborating organizational practices of other developing countries can be studied. Finally, we recommend further research aimed at other minority groups, such as the young trans or disabled workforce.

\section{Conclusion}

The study findings provide a broad indicator of the issues and the status and problems of the transcommunity in society. It also provides valuable evidence of how transgender persons' experience bias-motivated discrimination, stigmatization, violence, and harassment in different areas of life, mainly employment education, healthcare, housing, and other services. This study concludes that social exclusion is one of the many factors forcing the transgender community to indulge in inappropriate conduct. The findings strongly suggest that interventions to increase social inclusion, reduce gender-based discrimination, violence, and physical abuse, facilitate access to quality medical care, and inclusive education should be considered part of a comprehensive approach to preventing risky behavior in trans-populations.

The study has a significant social value in response to SDGs on preserving and valuing fundamental human rights. Once the trans-community is treated as normal humans, only then can trans people begin to imagine a world that respects their core personhood and a world in which dignity, equality, and well-being become realities in their lives.

\section{Acknowledgment}

The authors are grateful to the honorable editorial board members and anonymous reviewers for their guidance and encouragement.

\section{References}

Abreu, R. L., Gonzalez, K. A., Arora, S., Sostre, J. P., Lockett, G. M., \& Mosley, D. V. (2021). "Coming together after tragedy reaffirms the strong sense of community and pride we have:" LGBTQ people find strength in community and cultural values during the COVID-19 pandemic. Psychology of Sexual Orientation and Gender Diversity. Advance online publication. https://doi.org/10.1037/sgd0000516

Ahmed, U., Yasin, G., \& Umair, A. (2014). Factors affecting the social exclusion of eunuchs (hijras) in Pakistan. Mediterranean Journal of Social Sciences, 5(23), 2277-2277.

Atteberry-Ash. B., Walls, N. E., Kattari, S. K., Peitzmeier, S. K., Kattari, L., Langenderfer-Magruder, L. 2020. Forced sex among youth: accrual of risk by gender identity, sexual orientation, mental health, and bullying. Journal of LGBT Youth, 17(88), 1-21. https://doi.org/ 10.1080/19361653.2019.1614131

Balsam, K. F., Beadnell, B., \& Molina, Y. (2013). The Daily Heterosexist Experiences Questionnaire: Measuring minority stress among lesbian, gay, bisexual, and transgender adults. Measurement and Evaluation in Counseling and Development, 46(1), 3-25.

Basow, S. A., \& Thompson, J. (2012). Service providers' reactions to intimate partner violence as a function of victim sexual orientation and type of abuse. Journal of Interpersonal Violence, $27(7), 1225-1241$. 
Braun, V., and Clarke, V. (2013). Successful Qualitative Research: A Practical Guide for Beginners. London: Sage Publishers.

Burnes, T. R., Dexter, M. M., Richmond, K., Singh, A. A., \& Cherrington, A. (2016). The experiences of transgender survivors of trauma who undergo social and medical transition. Traumatology, 22(1), 75-84. https://doi.org/10.1037/trm0000064

Compton, d'Alene. 2019. "How many (queer) cases do I need?" Pp. 185-200 in Other, Please Specify Methods in Sociology, edited by D. Compton, T. Meadow, and K. Schilt. Berkeley: University of California Press.

Government of Pakistan (2013). Punjab Pakistan. retrieved from http://www.punjab.gov.pk/?q=punjab_quick_stats

De Lind van Wijngaarden, J. W., Schunter, B. T., \& Iqbal, Q. (2013). Sexual abuse, social stigma, and HIV vulnerability among young feminized men in Lahore and Karachi, Pakistan. Culture, Health \& Sexuality, 15(1), 73-84.

Divan, V., Cortez, C., Smelyanskaya, M., \& Keatley, J. (2016). Transgender social inclusion and equality: a pivotal path to development. Journal of the International AIDS Society, 19(3 Suppl 2), 20803. https://doi.org/10.7448/IAS.19.3.20803

Falak, S., \& Safdar, F. (2020). Perceived discrimination, social support, and psychological distress in transgender individuals. PsyCh Journal, 9(5), 682-690.

Hafiz, Nusrat, Samiha N. Majumdar, Mukit Anis, Ahmad Shaharudin Abdul Latiff, and Sazali Abd Wahab. 2021. "An Assessment of Diversity, Equity, and Inclusion Management Practices in the Small Businesses of Bangladesh." International Conference on Business and Management ( ${ }^{\text {rd }}$ ICBM, 2021). Dhaka, Bangladesh: BRAC University.

Hafiz, N., Azmi, K. M., Islam, A., Latiff, A.S. A., \& Wahab, S. A. (2022). Diversity \& Inclusion Experience of Trans Workers: The Missing Link of Trans-Friendly Environment in Organizations. Journal of International Business and Management, 5(2), 01-15. https://doi.org/10.37227/JIBM-2022-01-5293

Justin.E. Lerner. And Jane, J, Lee (2021) Transgender and Gender Diverse (TGD) Asian Americans in the United States: Experiences of Violence, Discrimination, and Family Support. https://doi.org/10.1177/08862605211056721

Kade, T. (2021). "Hey, by the way, I'm Transgender": Transgender Disclosures as Coming Out Stories in Social Contexts among Trans Men. Socius: Sociological Research for a Dynamic World, 7, 1-12. doi:https://doi.org/10.1177/23780231211039389

Khan, S. I., Hussain, M. I., Parveen, S., Bhuiyan, M. I., Gourab, G., Sarker, G. F., ... \& Sikder, J. (2009). Living on the extreme margin: social exclusion of the transgender population (Hijra) in Bangladesh. Journal of health, population, and nutrition, 27(4), 441.

Mal S. (2018). The hijras of India: A marginal community with paradox sexual identity. Indian J Soc Psychiatry 34:79-85. Retrieved from: http://www.indjsp.org.

Mirabella, M., Senofonte, G., Giovanardi, G., Lingiardi, V., Fortunato, A., Lombardo, F., \& Speranza, A. M. (2021). Psychological well-being of trans* people in Italy during the covid19 pandemic: Critical issues and personal experiences. Sexuality Research \& Social Policy: A Journal of the NSRC. Advance online publication. https://doi.org/10.1007/s13178-02100633-3

Mohydin, R. (2018). With transgender rights, Pakistan has an opportunity to be a path breaker. More, V. Problems Of Transgender Community In India: A Sociological Study.

Mughal, A. W., Aldridge, J., \& Monaghan, M. (2019). Perspectives of dropped-out children on their dropping out from public secondary schools in rural Pakistan. International Journal of Educational Development, 66, 52-61.

Rehan, N., Chaudhary, I., \& Shah, S. K. (2009). Socio-sexual behavior of hijras of Lahore. JPMA. The Journal of the Pakistan Medical Association, 59(6), 380.

Siddique, K. A. M. R. A. N., Mirbehar, S., Batool, H., Ahmad, I., \& Gang, C. (2017). Transgender Issues in the Pakistani community. European Academic Research, 4(10), 9048-9057.

Sterzing, P. R., Ratliff, G. A., Gartner, R. E., McGeough, B. L., \& Johnson, K. C. (2017). Socialecological correlates of poly victimization among a national sample of transgender, 
genderqueer, and cisgender sexual minority adolescents. Child Abuse and Neglect, 67, 112. http://dx.doi.org/ 10.1016/j.chiabu.2017.02.017

Shah, H. B. U., Rashid, F., Atif, I., Hydrie, M. Z., Fawad, M. W. B., Muzaffar, H. Z., ... \& Shukar, H. (2018). Challenges faced by marginalized communities such as transgender in Pakistan. The Pan African Medical Journal, 30.

Yasin, R., \& Jauhar, J. (2018). Discrimination with Trans Genders, A pathway for them to prostitution. International Journal of Academic Research in Business and Social Sciences, 8(1), 493-499.

Zamantakis, Alithia. 2020. "Queering Intimate Emotions: Trans/Nonbinary People Negotiating Emotional Expectations in Intimate Relationships." Sexualities. doi:10.1177/1363460720979307. 